\title{
Cockayne syndrome: report of a Brazilian family with confirmation of impaired RNA synthesis after UV-irradiation
}

\author{
Simone M. Karam ${ }^{1}$, Jaderson C. Costa ${ }^{2}$, Laura Jardim ${ }^{1,3}$, Ricardo F. Pires ${ }^{1}$, Alan R. Lehmann ${ }^{5}$ and Roberto Giugliani ${ }^{1,4}$
}

\begin{abstract}
Cockayne syndrome (CS) is an autosomal recessive disorder characterized by dwarfism, growth deficiency, neurological deterioration, skin photosensitivity and a characteristic progressive facial appearance. In the present study we report the first Brazilian CS family in which diagnosis was confirmed by the demonstration of decreased RNA synthesis in cultured fibroblasts exposed to UV-C radiation. Despite the progressive course of the disease and the unavailability of an effective treatment, diagnosis may be very important for the benefits to be gained by the afflicted family from genetic counseling and/or prenatal diagnosis.
\end{abstract}

\section{INTRODUCTION}

Cockayne syndrome (CS) is an autosomal recessive disorder caused by a mutation in one of two genes, CSA on chromosome 5 (Henning et al., 1995) or CSB on chromosome 10 (Troelstra et al., 1992). CS is very rare less than 200 cases having been reported in the literature (Cleaver and Kraemer, 1995). In its classical form (Cockayne syndrome type I or type A) it is characterized by loss of adipose tissue and severe postnatal growth retardation, starting in the first year of life and leading to a final stature of about $115 \mathrm{~cm}$.

By 2 years of age, almost all affected children present microcephaly. The central nervous system (CNS) is severely compromised, showing mild to severe mental retardation. Neurosensorial hearing loss has been reported in $50 \%$ of the cases. Other marked features are ataxia, tremor, poor coordination and dysartric speech. Seizures occur in 10\% of cases (Jones, 1997, Baraitser and Winter, 1998). Neuroimaging studies have identified calcifications in the basal ganglia, demyelination and cerebral atrophy (Sybert, 1997).

Ocular findings including abnormal retinal pigmentation, cataract and optic atrophy have been reported. CS patients also present sensitivity to sunlight, dry skin and extremities that are usually cold and cyanotic. A slender nose and deep-set eyes are also commonly observed (Jones, 1997). Skeletal abnormalities in CS patients include disproportionately long limbs, large hands and feet, and flexion joint contractures (McKusick, 1997). Micro- penis, cryptorchidism, hepatomegaly, splenomegaly, osteoporosis, hypertension and altered renal function have also been reported in some CS patients (Jones, 1997).

A second type of CS (type II or B), has been reported in 20 cases. In these patients, signs and symptoms start earlier and are more severe than those observed in CS type I. The early manifestation of CS type II usually allows its diagnosis at birth. Patients with CS type II have a lower survival rate, mean age at death being between 6 and 7 years (Toriello, 1990).

A defect in DNA repair documented in fibroblasts of CS patients, is manifested by increased sensitivity of $\mathrm{CS}$ cells to ultraviolet (UV) radiation and decreased recovery of RNA synthesis after UV exposure. Whereas global excision repair is normal (Jones, 1997; Lehmann, 1985) decreased transcription-coupled repair of UV damage in active genes is defective (van Hoffen et al., 1993).

This is the first report of CS in a Brazilian family, confirmed by the observation of impair RNA synthesis following UV-C radiation of CS fibroblasts.

\section{CASE REPORT}

Patient A.P., a girl, was the third child of healthy consanguineous parents (first cousins), of Italian origin. Pregnancy and term delivery were normal. Birth weight was $2,800 \mathrm{~g}$.

Neuropsychomotor development was delayed, in special language skills. From 4-5 years, she started to present neurological regression, a pyramidal-ataxic syndrome and

${ }^{1}$ Serviço de Genética Médica, Hospital de Clínicas de Porto Alegre, Rua Ramiro Barcelos, 2350, 90035-003 Porto Alegre, RS, Brasil. Send correspondence to R.G. Fax: +55-51-316-8010. E-mail: rgiugliani@hcpa.ufrgs.br

${ }^{2}$ Serviço de Neurologia, Hospital São Lucas da PUC, Porto Alegre, RS, Brasil. Departamentos de ${ }^{3}$ Medicina Interna and

${ }^{4}$ Genética, UFRGS, Porto Alegre, RS, Brasil.

${ }^{5}$ MRC Cell Mutation Unit, University of Sussex, UK. 
seizures. The child also showed marked redness upon minimal exposure to the sun.

Screening for inborn metabolic errors included assays of hexaminidase, beta-glucuronidase, arylsulfatase A and galactocerebrosidase activities. Immunoglobulins, uroporphyrin and coproporphyrin levels were also assessed. All were normal.

At the age of eight years and 10 months, anthropometric examination indicated short stature $(118 \mathrm{~cm}$, below the 5 th percentile), low weight $(18.8 \mathrm{~kg}$, below the 5 th percentile) and microcephaly (cephalic circumference $46.2 \mathrm{~cm}$, below the 3rd percentile) (Needlman, 1995). Sunken eyes, loss of facial adipose tissue, slender nose, large ears (Figure 1), narrow palate and dental caries were also noticed.

Neurological examination showed ataxia, diffuse hyporreflexia and insensitivity to vibration in the lower limbs. Magnetic resonance image (MRI) was normal and electromyography revealed myelinic neuropathy.

A fibroblast culture was established from a skin biopsy in order to study the effect of UV radiation on RNA synthesis. Following UV-irradiation, RNA synthesis failed to recover (Figure 2), confirming the diagnosis of CS.

According to the parents, the oldest brother had presented similar clinical features. At 14 months of age, he was unable to hold objects, clearly demonstrating a delay in neuropsychomotor development (8). At 5 years, he developed seizures and lost acquired skills, such as speech and walking. He also presented facial erythema when exposed to sunlight. Microcephaly and neurological signs similar to the index case were also reported. Computed tomography (CT scan) showed cerebral atrophy. He died at the age of 19 years, bed-ridden.

\section{DISCUSSION}

The patient's clinical findings are similar to those observed in other CS patients. Microcephaly is one of the most important findings (Sybert, 1997). Other significant features of CS like deep-set eyes, large and prominent ears, thin nose, progeroid face, deafness, dental caries and sun sensitivity, were also observed in our patients.

Regarding differential diagnoses, progeria syndrome, xeroderma pigmentosum (XP) and Seckel's syndrome were the main disorders to be excluded. Mental retardation, neurological deterioration, growth failure, ocular changes and cutaneous sensitivity are the major features to be considered for the diagnosis of CS. The presence of mental deterioration helps to exclude progeria and Seckel's syndrome as a possible alternative diagnosis (Houston et al., 1982). Xeroderma pigmentosum is associated with several clinical and biochemical findings similar to those observed in CS patients, including UV photosensitivity, mental retardation, complex nervous system abnormalities and cutaneous pigmentary changes. Patients with CS are, however, clinically distinguishable from those with

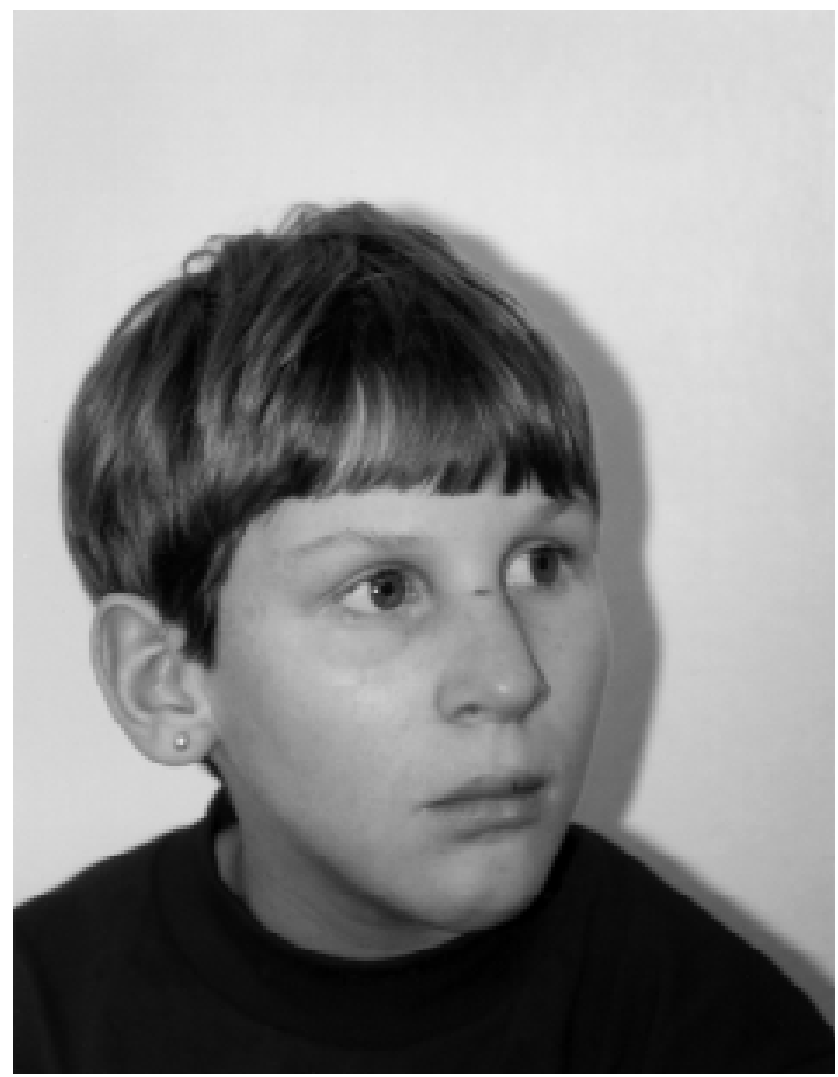

Figure 1 - Patient A.P. at the age of 8 years, presenting typical features of Cockayne syndrome (thin face, slender nose, deep-set eyes and large ears).

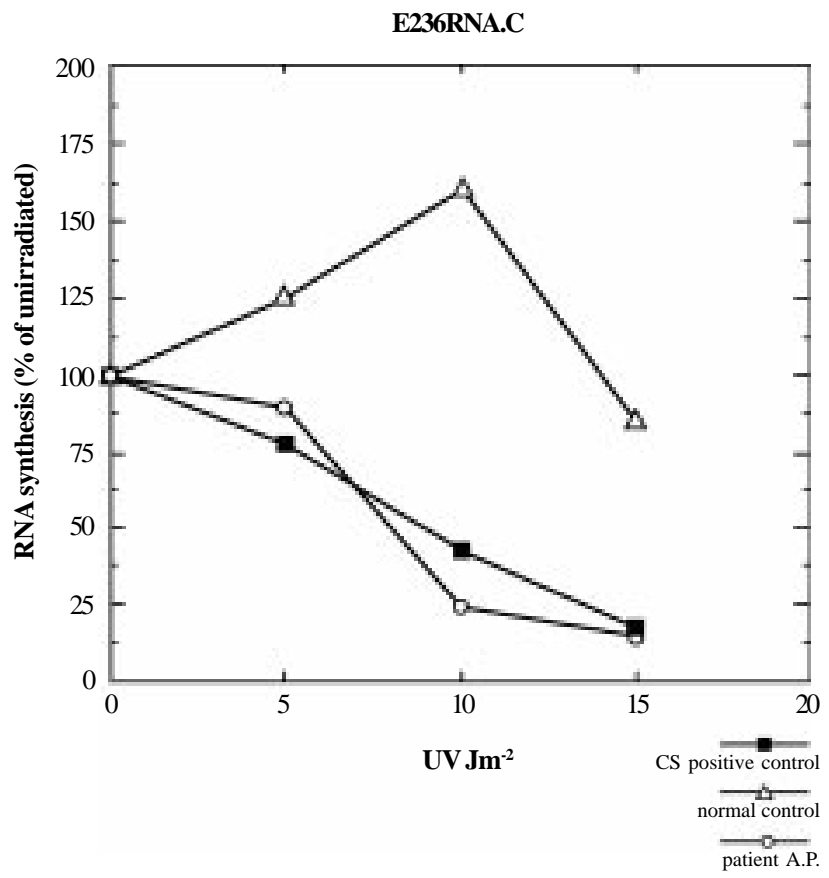

Figure 2 - RNA synthesis in cultured fibroblasts (from patient, CS positive control and normal control) measured by the incorporation of ${ }^{3} \mathrm{H}$ uridine into RNA $24 \mathrm{~h}$ after exposure to UV-C radiation. Results are expressed as the percentage of the RNA synthesis observed in non-irradiated fibroblasts. 
XP by, among other things, the presence of cachetic dwarfism, pigmentary retinal degeneration and the absence of actinically induced cancer (Greenhaw et al., 1992).

To summarize, a diagnosis of CS was suspected from the clinical findings, in special, neurological and dermatological signs. CT and/or MRI can assist in the investigation, but the measurement of RNA synthesis in cultured fibroblasts exposed to UV-C radiation is the definitive diagnostic procedure (Lehmann et al., 1993). Despite the lack of effective treatment and the progressive course of the disease, its correct diagnosis is very important to assist the family with genetic counseling (Houston et al., 1982) and prenatal diagnosis (Lehmann, 1985).

\section{ACKNOWLEDGMENTS}

We are grateful to Heather Fawcett for assistance with the RNA synthesis experiments.

\section{RESUMO}

A síndrome de Cockayne (CS) é uma desordem autossômica recessiva caracterizada por nanismo, déficit de crescimento, deterioração neurológica, fotossensibilidade e uma progressiva aparência facial característica. Neste artigo relatamos a primeira família brasileira com CS, cujo diagnóstico foi confirmado pela demonstração de uma síntese diminuída de RNA na cultura de fibroblastos expostos à radiação ultravioleta. Apesar do curso progressivo da doença e da inexistência de um tratamento efetivo, o diagnóstico faz-se muito importante, pois a família pode se beneficiar do aconselhamento genético e/ou do diagnóstico pré-natal.

\section{REFERENCES}

Baraitser, M. and Winter, R.M. (1998). Cockayne syndrome. In: London Dismorphology Databases. Oxford University Press, Oxford (CD).

Cleaver, J.E. and Kraemer, K.H. (1995). Xeroderma pigmentosum and
Cockayne syndrome. In: The Metabolic and Molecular Bases of Inherited Disease (Scriver, C.R., Beaudet, A.L., Sly, W.S. and Valle, D., eds.). McGraw-Hill, New York, pp. 4397.

Greenhaw, G.A., Herbert, A., Duke-Woodside, M.E., Butler, I.J., Hecht, J.T., Cleaver, J.E., Thomas, G.H. and Horton, W.A. (1992). Xeroderma pigmentosum and Cockayne syndrome: Overlapping clinical and biochemical phenotypes. Am. J. Hum. Genet. 50: 677-689.

Henning, K.A., Li, L., Iyer, N., McDaniel, L.D., Reagan, M.S., Legerski, R., Schultz, R.A., Stefanine, M., Lehmann, A.R., Mayne, L.V. and Friedberg, E.C. (1995). The Cockayne syndrome group A gene encodes a WD repeat that interacts with CSB protein and a subunit of RNA polymerase II TFIIH. Cell 82: 555-564.

Houston, C.S., Zaleski, W.A. and Rozdilski, B. (1982). Identical male twins and brother with Cockayne syndrome. Am. J. Med. Genet. 13: 211-223.

Jones, K.L. (Ed.) (1997). Cockayne syndrome. In: Smith's Recognizable Patterns of Human Malformation. W.B. Saunders, Philadelphia, pp. 145146.

Lehmann, A.R. (1985). Prenatal diagnosis of Cockayne syndrome. Lancet 2: 486 .

Lehmann, A.R., Thompson, A.F., Harcourt, S.A., Stefanini, M. and Norris, P.G. (1993). Cockayne's syndrome: Correlations of clinical features with cellular sensitivity of RNA synthesis to UV irradiation. J. Med. Genet. 30: 679-682.

Needlman, R.D. (1995). Growth and development. In: Nelson Textbook of Pediatrics (Behrman, R.E., Kliegman, M.R. and Arvin, A.M., eds.) (Nelson, W.E., ed. senior). 15th edn. W.B. Saunders, Philadelphia, pp. 49-52.

McKusick, V.A. (Ed.) (1997). Cockayne syndrome. In: Mendelian Inheritance in Man. A Catalog of Human Genes and Genetic Disorders. The Johns Hopkins University Press, Baltimore.

Sybert, V. (1997). Cockayne syndrome. In: The Genetic of Skin Disorders. Oxford University Press, Oxford.

Toriello, H.V. (1990). Cockayne syndrome type II. In: The Birth Defects Encyclopedia (Buyse, M.L., ed.). Blackwell Scientific Publications, Cambridge, pp. 422.

Troelstra, C., Landsvater, R.M., Wiegant, J., van der Ploeg, M., Viel, G., Buys, C.H.C.M. and Hoeijmakers, J.H.J. (1992). Localization of the nucleotide excision repair gene ERCC6 to human chromosome 10q11q21. Genomics 12: 745-749.

van Hoffen, A., Natarajan, A.T., Mayne, L.V., van Zeeland, A.A., Mullenders, L.H.F. and Venema, J. (1993). Deficient repair of the transcribed strand of active genes in Cockayne's syndrome cells. Nucleic Acids Res. 21: 5890-5895.

(Received January 5, 2000) 
